\title{
Sputum and plasma endothelin-1 levels in exacerbations of chronic obstructive pulmonary disease
}

M Roland, A Bhowmik, R J Sapsford, T A R Seemungal, D J Jeffries, T D Warner, J A Wedzicha

\begin{abstract}
Background-Endothelin (ET)-1 is a bronchoconstrictor peptide produced in the airways. It has been implicated in the pathogenesis of asthma and virally mediated airway inflammation and may play a role in exacerbations of chronic obstructive pulmonary disease (COPD).

Methods-Seventy one patients with COPD were followed prospectively and sampled for plasma and sputum ET-1 levels when stable and during an exacerbation. Sputum was also examined for cytokines, human rhinovirus, and Chlamydia pneumoniae.

Results-Plasma ET-1 levels were available for 67 patients with stable COPD (mean (SD) $0.58(0.31) \mathrm{pg} / \mathrm{ml})$; 28 pairs of stable-exacerbation plasma samples had a mean stable ET-1 level of $0.54(0.30) \mathrm{pg} / \mathrm{ml}$ rising to $0.67(0.35) \mathrm{pg} / \mathrm{ml}$ at exacerbation (mean difference $0.13,95 \%$ confidence interval (CI) 0.04 to $0.21, p=0.004)$. Plasma ET-1 levels in the 67 patients with stable COPD were inversely correlated with baseline forced expiratory volume in one second $\left(\mathrm{FEV}_{1} ; r=-0.29, \mathrm{p}=0.022\right)$ and forced vital capacity (FVC; $r=-0.38, p=$ $0.002)$. The change in plasma ET-1 levels during an exacerbation correlated with the change in oxygen saturation $\left(\mathrm{SaO}_{2} ; \boldsymbol{r}=\right.$ $-0.41, p=0.036$ ). In 14 stable-exacerbation pairs of sputum samples median stable ET-1 levels were $5.37(0.97-21.95) \mathrm{pg} / \mathrm{ml}$ rising to $34.68(13.77-51.95) \mathrm{pg} / \mathrm{ml}$ during an exacerbation (mean difference 25.14, $95 \%$ CI 3.77 to $46.51, p=0.028)$. This increase in sputum ET-1 levels correlated with the increase in plasma ET-1 levels ( $r$ $=0.917, \mathrm{p}=0.001)$ and sputum interleukin (IL) -6 levels $(r=0.718, p=0.013)$.

Conclusions-Sputum levels of ET-1 rise in COPD patients during an exacerbation and this is reflected by a smaller rise in plasma ET-1 levels. ET-1 may have a role in mediating airway inflammatory changes during exacerbations of COPD. (Thorax 2001;56:30-35)
\end{abstract}

Keywords: endothelin-1; chronic obstructive pulmonary disease; inflammation; cytokines; sputum

Endothelin-1 (ET-1) is a potent vasoconstrictive and bronchoconstrictive peptide that has been implicated in the pathophysiology of asthma. ${ }^{12}$ ET-1 is raised in the airways of asth- matic subjects and has been shown to stimulate mucus secretion, airway oedema, smooth muscle mitogenesis, and also bronchial hyperresponsiveness. ${ }^{3}$ It is also thought to have important pro-inflammatory effects in the airways, being both a chemoattractant and an upregulator of other inflammatory mediators such as the interleukins IL-6 and IL-8, and granulocyte-macrophage colony stimulating factor (GM-CSF). ${ }^{4}$ There are several sites of ET-1 production within the human lung including the bronchial epithelium, pulmonary endothelium, and alveolar macrophages. ${ }^{5-7}$ The synthesis of ET-1 is inducible by hypoxia and viruses, ${ }^{89}$ with systemic rises occurring in response to various factors including ischaemia, shock, and sepsis. Several cytokines, including tumour necrosis factor (TNF)- $\alpha$, may act as intermediaries in this process. ${ }^{10}$

To date there has only been limited work on the role of ET-1 in chronic obstructive pulmonary disease (COPD). Chalmers et al reported increased sputum ET-1 levels at baseline compared with normal controls with no significant differences in baseline plasma levels, ${ }^{11}$ and Sofia et al found increased 24 hour urinary excretion of ET-1 in patients with COPD compared with controls. ${ }^{12}$ Patients with COPD are prone to exacerbations associated with increased airway inflammation, and respiratory virus infections are an important cause of such exacerbations. ${ }^{13-15}$ Interestingly, viruses have been shown to induce airway ET-1 production in animal models, which suggests that ET-1 may have an important role in the pathophysiology of COPD exacerbations. ${ }^{9}$

In this study we have prospectively measured plasma and sputum ET-1 levels in a cohort of outpatients with COPD, both when stable and at diagnosis of an exacerbation. We have also investigated the relationships at exacerbation between sputum ET-1 levels and cytokine production, symptoms, lung function changes, and the presence of infection.

\section{Methods}

SUBJECTS

Seventy one patients with a diagnosis of moderate to severe COPD, recruited from the outpatient department of the London Chest Hospital, volunteered to participate in the study. These patients are part of a cohort of patients with COPD who have been followed since October 1995 in the East London COPD study. This study represents a rolling cohort of COPD patients and, as such, some patients 
described in a previous paper ${ }^{13}$ have also been sampled for the current study. The data presented here represent a completely new sample set taken at later dates than those samples presented previously. COPD was defined as forced expiratory volume in one second $\left(\mathrm{FEV}_{1}\right)$ of $<70 \%$ predicted for age and height, and salbutamol reversibility of $<15 \%$ or $200 \mathrm{ml}$ with airflow obstruction evidenced by a ratio of $\mathrm{FEV}_{1}$ to forced vital capacity (FVC) of $<70 \%{ }^{16}$ Patients with a history of asthma, bronchiectasis, carcinoma of the bronchus, or other significant respiratory disease were excluded. All patients had received influenza immunisation as recommended for this patient group. Smoking and treatment history was taken. Sixty five patients $(92 \%)$ were taking inhaled corticosteroids on a regular basis. Patients were recruited when stable - that is, when they had not had any evidence of an exacerbation during the previous three weeks. Baseline measurements were made of $\mathrm{FEV}_{1}, \mathrm{FVC}$, and peak expiratory flow rate (PEF) by rolling seal spirometer (SensorMedics Ltd, Yorba Linda, CA, USA), reversibility to salbutamol, and ear lobe capillary blood gas tensions (Model 278 Blood Gas Analyser, Ciba-Corning, Medfield, MA, USA). ${ }^{17}$ Baseline plasma, nasal aspirate, and sputum samples were also taken when available.

The study was approved by the City and East London Health Authority research ethics committee and written informed consent was obtained from each patient. The treatment received by the patients was not changed during stable periods.

\section{DIAGNOSIS OF EXACERBATIONS}

The patients maintained daily diary cards at home after completing their morning medication on which they noted their daily PEF using a mini-Wright peak flow meter (Clement Clarke International Ltd, Harlow, UK) and any changes in symptoms from their baseline conditions. Exacerbations were diagnosed according to criteria modified from Anthonisen and colleagues and used in our previous studies. ${ }^{18}{ }^{19}$ The following symptom patterns had to be experienced for at least two consecutive days for the diagnosis to be made: any two of three major symptoms (increase in dyspnoea, sputum purulence, and increased sputum volume) or at least one major symptom together with at least one of the following minor symptoms - a cold (increase in nasal discharge or congestion), wheeze, sore throat, cough, or fever. When patients noticed a deterioration in symptoms they telephoned a member of the clinical team and were seen by a doctor within 48 hours. The diagnosis of the exacerbation was confirmed in each case by a doctor in the study team. Spirometric parameters and oxygen saturation were measured and nasal aspirates and a plasma sample were taken. Where spontaneous sputum was available a sample was taken, otherwise sputum induction was performed. No treatment was started for the exacerbation (antibiotics and/or oral corticosteroids and/or increased inhaled steroids) before sampling. After sampling such treatment as would normally have been prescribed was started on an outpatient basis.

The exacerbation frequency was defined as the number of exacerbations suffered by each patient during the previous year. Patients had been followed by our team for one year before sampling and this information was obtained from the diary cards. The number of symptoms which appeared or showed an increase in intensity on any day, out of those major and minor symptoms listed above, was the symptom score for that day. Changes in $\mathrm{PEF}, \mathrm{FEV}_{1}$, FVC, and increase in the daily symptom score were calculated as the difference between the day of onset and the baseline value. The baseline PEF was calculated as the mean PEF from 14 days to 7 days before the onset of symptoms.

SPUTUM COLLECTION AND PROCESSING

Stable sputum samples were collected from the patients at least two months away from an exacerbation where possible. In cases where stable samples could not be obtained before an exacerbation, samples were taken at least three weeks following the exacerbation. Samples were also obtained during exacerbations before treatment was prescribed. Thirty sputum samples were produced spontaneously and 13 were induced when spontaneous sputum was not available. Sputum induction was performed according to a protocol described previously by our group. ${ }^{20}$ Sputum samples were examined as soon as possible (within two hours) adapting methods previously evaluated. ${ }^{21}$ The weight of the total sample was recorded. The sputum was then separated from contaminating saliva by macroscopic examination using a pair of disposable plastic forceps and then divided into two approximately equal portions. Both selected portions of sputum were placed in preweighed tubes and their weights recorded. The first portion of sputum was mixed with nine times its weight of phosphate buffered saline (PBS) and several siliconised glass beads (BDH Chemicals Ltd, Poole, Dorset, UK) were added to facilitate mechanical breakdown of the sputum sample. This mixture was then agitated until a homogeneous solution was formed, filtered through $50 \mu \mathrm{m}$ nylon gauze to remove mucus and debris without removing any of the cells, and then centrifuged at $790 \mathrm{~g}$ $(2000 \mathrm{rpm})$ for 10 minutes. The supernatant was decanted off and $10 \mu \mathrm{l} / \mathrm{ml}$ of a peptidase inhibitor solution was added. This peptidase inhibitor solution contained a mixture of captopril, bestatin, DL-thiorphan, and bacitracin (all from Sigma Aldrich, Poole, Dorset, UK) and its exact composition and use in preventing ET breakdown have been described previously by Moggi et al..$^{22}$ The sample was again stored at $-70^{\circ} \mathrm{C}$ until ready for analysis. ET-1 levels were measured from this PBS treated sample using a sandwich enzyme linked immunosorbent assay (R \& D Systems). The PBS sample was used for the ET-1 assay as Chalmers et al had previously found that dithiothreitol treatment altered the standard curve for their ET-1 assays. ${ }^{11}$

The second portion of sputum was then mixed with four times its weight of freshly pre- 
Table 1 Mean (SD) characteristics of study group $(n=71)$

\begin{tabular}{ll}
\hline Age & $68.2(7.8)$ \\
$\mathrm{FEV}_{1}(1)$ & $1.1190 .40)$ \\
$\mathrm{FVC}(1)$ & $2.63(0.74)$ \\
$\mathrm{PEF}(1 / \mathrm{s})$ & $2.82(1.16)$ \\
$\mathrm{FEV}_{1} / \mathrm{FVC}(\%)$ & $43.1(13.6)$ \\
$\mathrm{FEV}_{1}(\%)$ & $39.8(17.0)$ \\
$\mathrm{Reversibility}(\%)_{\mathrm{PaO}_{2}(\mathrm{kPa})}$ & $9.09(12.26)$ \\
$\mathrm{PaCO}_{2}(\mathrm{kPa})$ & $9.00(1.00)$ \\
Pack years $_{\text {Current smokers }(\%)}$ & $5.87(0.85)$ \\
& $34.6(34.1)$ \\
\hline
\end{tabular}

$\mathrm{FEV}_{1}=$ forced expiratory volume in one second $\mathrm{FVC}=$ forced vital capacity; $\mathrm{PEF}=$ peak expiratory rate $\mathrm{PaO}_{2}, \mathrm{PaCO}_{2}=$ arterial oxygen and carbon dioxide tensions.

pared $0.1 \%$ dithiothreitol solution made by mixing the dithiothreitol powder with Hank's Balanced Salt Solution (HBSS). This was vortexed for 15 seconds and then rocked for 15 minutes. A weight of HBSS equal to that of the sputum plus dithiothreitol was added and the whole mixture rocked for another five minutes. The solution was then filtered and centrifuged in the same manner as the first sputum portion. This resulted in the formation of a cell pellet and a supernatant solution. The supernatant was decanted off and stored at $-70^{\circ} \mathrm{C}$ for future analysis and the cell pellet was resuspended in 0.4-3.2 ml HBSS (depending on macroscopic estimation of the size of the cell pellet). The total cell count was determined with a Neubauer haemocytometer using the trypan blue exclusion method to determine cell viability, blue cells being counted as non-viable. ${ }^{20}$ The absolute number of non-squamous cells/g original sputum sample was determined and the percentage of viable and non-viable cells obtained. The cell suspension was then mixed with HBSS to obtain a count of $0.6-1.0 \times 10^{6}$ cells $/ \mathrm{ml}$ of the suspension. Cytospins were made using a Cytotek cytocentrifuge. The cytospin slides were stained with Diff-Quik to obtain differential cell counts made by counting 400 cells per slide. IL-6 and IL- 8 were measured in the supernatant samples using a quantitative sandwich immunoassay (R\&D Systems Europe, Abingdon, Oxon, UK) and expressed as $\mathrm{pg} / \mathrm{ml}$ of the supernatant. The supernatant itself was a 10 -fold dilution by weight of the original sputum sample minus cells.

PLASMA

Plasma samples for ET-1 analysis were taken at baseline and during an exacerbation into an ethylenediaminetetraacetic acid (EDTA) tube and immediately placed on ice. The samples were centrifuged within one hour of being

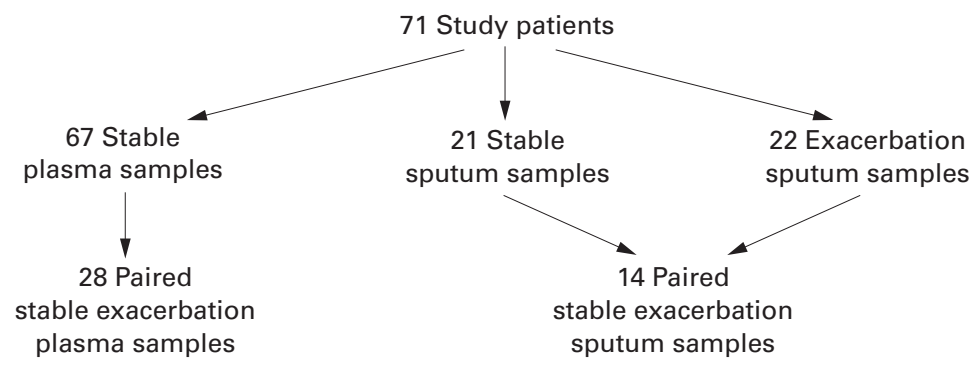

Figure 1 Distribution and sample size of the sputum and plasma sets described. taken at $790 \mathrm{~g}(2000 \mathrm{rpm})$ for 10 minutes. The supernatant was then aspirated off and $10 \mu \mathrm{l} /$ $\mathrm{ml}$ of peptidase inhibitor was mixed with it prior to storage at $-70^{\circ} \mathrm{C}$. ET-1 levels were measured in this plasma sample using the same ELISA method used for sputum following an extraction procedure described by the manufacturer (R \& D Systems).

NASAL ASPIRATES

Nasal aspirates were taken at baseline and during an exacerbation using a $\mathrm{CH} 10$ nasal catheter (Maerst Medical, Hundested, Denmark). If the volume of nasal aspirate was less than $0.5 \mathrm{ml}$, rhinorrhoea was induced by spraying into each nostril $0.1 \mathrm{ml}$ of a solution of histamine (BDH Chemicals, Poole, UK) made up freshly each day in $0.9 \%$ sodium chloride to a concentration of $8 \mathrm{mg} / \mathrm{ml}$. If the volume of nasal aspirate was still low, swabs of the anterior nares, pharynx, and tonsils were taken and immediately immersed in PBS. Both nasal aspirates and swabs were stored at $4^{\circ} \mathrm{C}$ and transported to the laboratory within four hours. At the laboratory PBS was added to each aspirate or swab to a final volume of $3.25 \mathrm{ml}$ and $0.25 \mathrm{ml}$ aliquots were stored at $-70^{\circ} \mathrm{C}$ for further analysis by polymerase chain reaction (PCR). One aliquot was taken for rhinoviral culture. Nasal aspirate and sputum samples were analysed for rhinovirus using a reverse transcriptase PCR (RT-PCR) method with rhinovirus specific primers. ${ }^{23}$ The same

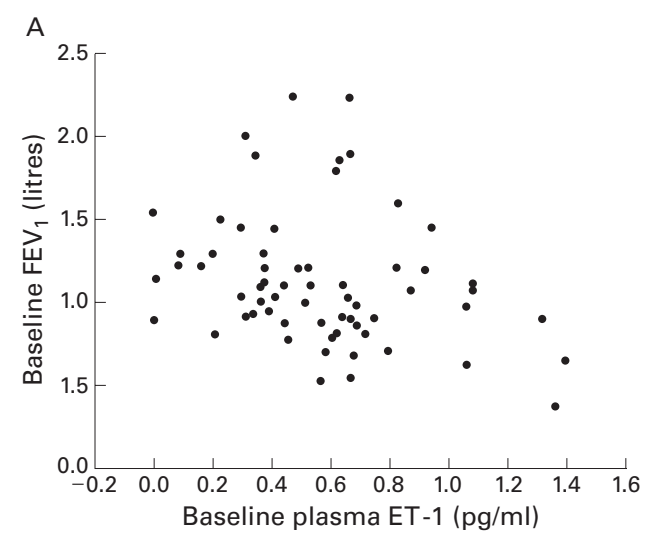

B

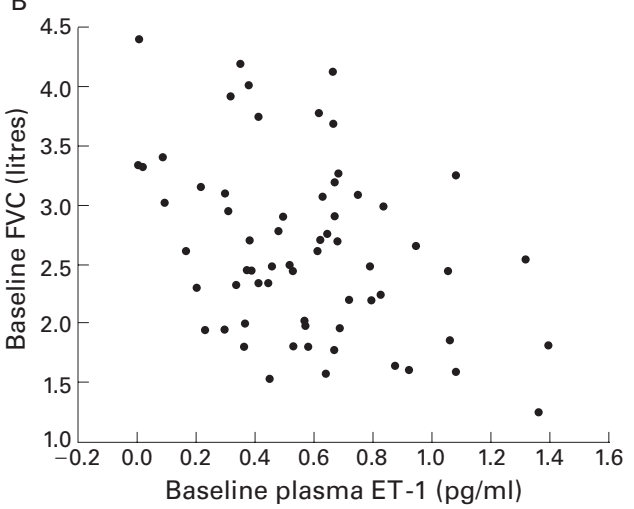

Figure 2 Baseline plasma endothelin-1 (ET-1) levels versus $(A)$ baseline forced expiratory volume in one second (FEV, $, n=67, r=-0.286, p=0.022$ and (B) baseline forced vital capacity (FVC), $n=67, r=-0.382, p=$ 0.002 . 
Table 2 Median (IQR) physiological indices at stable state and during an exacerbation for paired plasma $(n=28)$ and paired sputum $(n=14)$ subsets

\begin{tabular}{llll}
\hline & Stable & Exacerbation & p value \\
\hline Plasma & & & \\
FEV $_{1}(1)$ & $1.03(0.80-1.30)$ & $1.03(0.87-1.31)$ & 0.956 \\
$\mathrm{FVC}_{\mathrm{PEF}(1 / \mathrm{s})}$ & $2.36(2.11-3.18)$ & $2.29(1.51-2.91)$ & 0.237 \\
$\mathrm{SaO}_{2}(\mathrm{kPa})$ & $2.50(1.87-3.67)$ & $2.48(2.01-3.21)$ & 0.759 \\
$\mathrm{Sputum}_{\mathrm{FEV}}(1)$ & $94.0(92.0-95.0)$ & $93.0(91.0-94.8)$ & 0.431 \\
$\mathrm{FVC} \mathrm{(1)}$ & & & \\
$\mathrm{PEF}_{\mathrm{SE}}(1 / \mathrm{s})$ & $1.15(0.98-1.47)$ & $1.08(0.77-1.28)$ & 0.161 \\
$\mathrm{SaO}_{2}(\mathrm{kPa})$ & $2.75(2.06-3.53)$ & $2.38(1.85-3.26)$ & 0.401 \\
& $3.57(2.32-4.35)$ & $2.29(2.05-3.07)$ & 0.012 \\
& $94.0(91.8-96.0)$ & $93.0(91.0-95.0)$ & 0.499
\end{tabular}

$\mathrm{FEV}_{1}=$ forced expiratory volume in one second $\mathrm{FVC}$ = forced vital capacity; $\mathrm{PEF}$ = peak expiratory flow; $\mathrm{SaO}_{2}=$ oxygen saturation.

Table 3 Median (IQR) stable versus exacerbation values for sputum markers and plasma endothelin-1 (ET-1) levels in paired sputum subsets $(n=14)$

\begin{tabular}{llll}
\hline & Stable & Exacerbation & p value \\
\hline Sputum ET-1 $(\mathrm{pg} / \mathrm{ml})$ & $5.37(0.97-21.95)$ & $34.68(13.77-51.95)$ & 0.028 \\
IL-6 $(\mathrm{pg} / \mathrm{ml})$ & $181(61-249)$ & $181(35-261)$ & 0.594 \\
IL-8 $(\mathrm{pg} / \mathrm{ml})$ & $802(321-1618)$ & $789(183-1745)$ & 0.594 \\
TCC $\left(\times 10^{6} / \mathrm{ml}\right)$ & $1.24(0.24-5.97)$ & $2.71(1.98-17.98)$ & 0.111 \\
Neutrophils $\left(\times 10^{6} / \mathrm{ml}\right)$ & $1.08(0.14-4.26)$ & $1.97(1.29-15.46)$ & 0.142 \\
Macrophages $\left(\times 10^{6} / \mathrm{ml}\right)$ & $0.20(0.06-1.10)$ & $0.52(0.36-1.71)$ & 0.086 \\
Lymphocytes $\left(\times 10^{6} / \mathrm{ml}\right)$ & $0.06(0.03-0.59)$ & $0.24(0.15-0.72)$ & 0.142 \\
Eosinophils $\left(\times 10^{6} / \mathrm{ml}\right)$ & $0.24(0.15-0.72)$ & $0.10(0.00-0.11)$ & 0.917 \\
Plasma ET-1 $(\mathrm{pg} / \mathrm{ml})$ & $0.49(0.23-0.86)$ & $0.61(0.36-0.84)$ & 0.173 \\
\hline
\end{tabular}

samples were also analysed for Chlamydia pneumoniae by nested DNA and RT-PCR, again using specific primers. ${ }^{24}$

STATISTICAL ANALYSIS

Data on baseline age, spirometric parameters, and blood gas tensions for the 71 study patients and ET- 1 levels in the 67 stable plasma samples as well as the 28 paired stable-exacerbation plasma samples followed a normal distribution and were expressed as mean (SD) values with interrelationships examined using Pearson's correlation and $t$ test. All other variables were not normally distributed and therefore were expressed as medians with interquartile ranges and interrelationships were examined using Spearman's correlation, Mann-Whitney U test, and Wilcoxon signed ranks test as appropriate. The statistical package SPSS for Windows (version 10.0) was used for all data analysis.

\section{Results}

The baseline characteristics for the 71 patients with COPD are summarised in table 1 . The exact distribution and sample size of the sputum and plasma sets described below are illustrated in fig 1 . There were no significant differences in baseline characteristics between the sets described. Baseline plasma samples were available for 67 patients with a mean (SD) stable plasma ET-1 level of $0.58(0.31) \mathrm{pg} / \mathrm{ml}$. This was inversely correlated with baseline $\mathrm{FEV}_{1}(r=-0.286, \mathrm{p}=0.022)$ and FVC $(r=$ -0.382 , p $=0.002$; figs $2 \mathrm{~A}$ and $\mathrm{B}$ ). Baseline plasma ET-1 levels were unrelated to baseline $\mathrm{PaO}_{2}(r=0.140, \mathrm{p}=0.259), \mathrm{PaCO}_{2}(r=0.178$, $\mathrm{p}=0.149)$ and to the exacerbation frequency $(r$ $=-0.038, \mathrm{p}=0.764$ ).

In 28 patients paired baseline-exacerbation plasma samples were available. Baseline plasma ET-1 levels correlated inversely with baseline $\mathrm{FEV}_{1}(r=-0.473, \mathrm{p}=0.013)$ and FVC $(r=$ $-0.481, \mathrm{p}=0.011)$ in this group. The mean

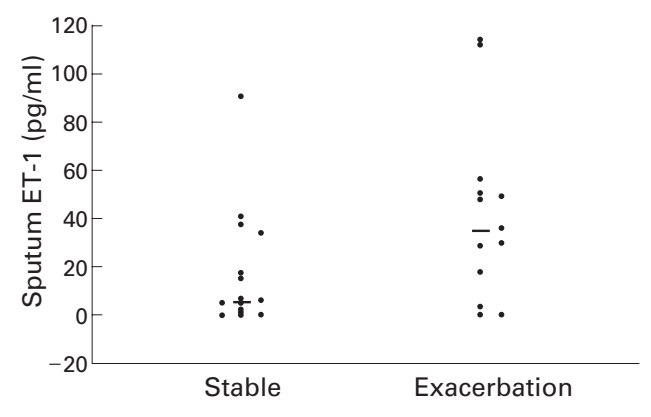

Figure 3 Baseline versus exacerbation sputum levels of endothelin-1 (ET-1) levels $(n=14)$; median (IQR) 5.37 (0.97-21.95) rising to 34.68 (13.77-51.95) shown as bars, $p=0.028$.

(SD) symptom score at exacerbation was 3.1 (1.4); changes in physiological parameters during an exacerbation for this group are given in table 2. Mean (SD) baseline plasma ET-1 levels were $0.54(0.30) \mathrm{pg} / \mathrm{ml}$, rising significantly at exacerbation to $0.67(0.35) \mathrm{pg} / \mathrm{ml}$ (mean difference $0.13,95 \%$ CI 0.04 to $0.21, \mathrm{p}=$ 0.004). The change in ET-1 levels was inversely related to the change in $\mathrm{SaO}_{2}$ between baseline and exacerbation $(r=-0.405, \mathrm{p}=0.036)$ but not to the symptom score $(r=0.147, \mathrm{p}=$ $0.455)$.

Twenty one stable and 22 exacerbation sputum samples were obtained from 29 patients. Among these samples there were 14 matched stable-exacerbation sputum pairs and the following results relate to the analysis of data pertaining to these paired samples. The exacerbation changes in physiological parameters for this group are given in table 2. The median symptom score for these exacerbations was 3.0 (2-4). The sputum ET-1 levels, cytokine levels, and cell counts together with the corresponding plasma ET-1 levels are given in table 3. The median (IQR) stable sputum ET-1 level was $5.37(0.97-21.95) \mathrm{pg} / \mathrm{ml}$ rising to $34.68(13.77-51.95) \mathrm{pg} / \mathrm{ml}$ at exacerbation (mean difference $25.14,95 \%$ CI 3.77 to 46.51 , $\mathrm{p}=0.028$; fig 3 ). Stable sputum and plasma ET-1 levels for this group were not related to any other measured parameters.

For this paired sputum group (table 4) the change in sputum ET-1 levels was related to both the change in plasma ET-1 levels $(r=$ $0.917, \mathrm{p}=0.001)$ and the change in sputum IL-6 levels $(r=0.718, p=0.013)$. The exacerbation frequency in the preceding year did not correlate with either the stable sputum ET-1 level $(r=-0.091, \mathrm{p}=0.758)$ or the rise in sputum ET-1 level during an exacerbation $(r=$ $0.153, p=0.601)$. The rise in sputum ET-1 level was not related to the dose of inhaled corticosteroids $(r=-0.298, \mathrm{p}=0.300)$.

An infective agent was identified in four of the 22 unpaired sputum exacerbation samples (two $C$ pneumoniae and two HRV). Median (IQR) exacerbation sputum ET-1 levels were 52.1 (37.4-172.1) $\mathrm{pg} / \mathrm{ml}$ for these four patients compared with $30.4(16.0-44.2) \mathrm{pg} / \mathrm{ml}$ for the rest of the group $(\mathrm{p}=0.073)$. Median exacerbation plasma ET-1 levels were higher in the infected group at $0.90(0.86-0.94) \mathrm{pg} / \mathrm{ml}$ compared with $0.55(0.44-0.77) \mathrm{pg} / \mathrm{ml}$ in the other patients $(\mathrm{p}=0.153)$. 
Table 4 Correlations between change in sputum endothelin-1 (ET-1) levels and changes in other measured parameters between stable state and exacerbation; paired sputum subsets $(n=14)$

\begin{tabular}{lll}
\hline & \multicolumn{2}{c}{ Change in sputum ET-1 } \\
\cline { 2 - 3 } & $r$ & p value \\
\hline Plasma ET-1 $(\mathrm{pg} / \mathrm{ml})$ & 0.917 & 0.001 \\
Sputum IL-6 $(\mathrm{pg} / \mathrm{ml})$ & 0.718 & 0.013 \\
Sputum IL-8 $(\mathrm{pg} / \mathrm{ml})$ & 0.118 & 0.729 \\
$\mathrm{SaO}_{2}(\mathrm{kPa})$ & -0.009 & 0.976 \\
$\mathrm{FEV}_{1}(\mathrm{l})$ & 0.452 & 0.260 \\
PEF $^{(1 / \mathrm{s})}$ & -0.143 & 0.736 \\
\hline
\end{tabular}

$\mathrm{FEV}_{1}=$ forced expiratory volume in one second; $\mathrm{PEF}=$ peak expiratory flow; $\mathrm{SaO}_{2}=$ oxygen saturation; $\mathrm{IL}=$ interleukin.

\section{Discussion}

ET-1 is an important bronchoconstrictor peptide produced in the airways with effects on a number of cell types. It has been implicated in the pathogenesis of asthma, allergic and virally mediated airway inflammation, and bronchial hyperresponsiveness. ${ }^{325}$ This study evaluated the role of ET-1 in COPD by examining patients when stable and, for the first time, during periods of exacerbation. Interestingly, rises in both plasma and sputum ET-1 levels were found during exacerbations, with the sputum showing relatively larger changes. Increased ET-1 production within the airway may contribute both to the airway obstruction and the increases in sputum production that are a common feature of exacerbations of COPD. ${ }^{19}$

The main site of ET-1 production within the airway is considered to be the bronchial epithelium with, for example, human epithelial cells cultured from asthmatic patients known to secrete more ET-1 than cells from healthy normal subjects. ${ }^{26}{ }^{27}$ Furthermore, induced sputum from stable asthmatic subjects contains much greater amounts of ET-1 than that from normal controls. ${ }^{28}$ We have recently shown that COPD exacerbations are associated with increases in airway inflammation and in airway IL-6 levels, with smaller changes in sputum cell counts. ${ }^{13}$ In the current study analysis of the paired samples showed that changes in sputum IL-6 levels were related to changes in ET-1 levels at exacerbation. In vitro work has shown ET to be a potent stimulus for IL-6 production from bronchial epithelial cells. ${ }^{4}$ IL-6 itself is a pro-inflammatory cytokine with effects on lymphocyte activation and immunoglobulin secretion, which will also act to promote endothelin production. This provides the potential for a positive feedback loop leading to exaggerated production of both ET-1 and IL-6. Corticosteroids have been shown to be partially effective in treating COPD exacerbations with earlier improvement in lung function. ${ }^{29}$ They can reduce ET-1 production from airway epithelial cells ${ }^{26}$ and this may be one of the mechanisms responsible for the benefits of steroids in exacerbations of COPD. Furthermore, endothelin receptor antagonists have now been developed which produce a significant reduction of ET related effects in various diseases - as well as in animal models of airway inflammation-and thus may potentially offer benefits in COPD exacerbations. ${ }^{30} 31$

Viral infections, especially the common cold virus (rhinovirus), have been shown to be an important cause of COPD exacerbations. ${ }^{14} 15$ Experimental inoculation of rhinovirus in healthy and asthmatic subjects ${ }^{32}$ is associated with increases in sputum IL-6 levels with infection, although effects on ET-1 levels have not been studied. One study in mice inoculated with influenza showed increased production of ET-1 in the airway epithelium associated with infection. ${ }^{9}$ In this study we isolated infectious agents from four of the exacerbations. ET-1 was found to be higher in the sputum and plasma of COPD patients with documented viral or chlamydial infection than in the sputum and plasma of those without, though the difference did not reach statistical significance. The relationship between airway ET-1 levels and viral infection at exacerbation requires further study.

The changes in plasma ET-1 levels in our study were small but were related to the sputum ET-1 levels and it is possible that the increased plasma ET-1 levels originate from increased airway ET-1 production. It is unlikely that the small changes in plasma ET-1 levels had any physiological effect, though changes in plasma levels of ET-1 at exacerbations were higher in those patients with greater changes in arterial oxygen saturation. Hypoxia is an important stimulus for ET-1 production, which has been implicated in the genesis of pulmonary hypertension and cor pulmonale. ${ }^{8}$ However, here we studied only outpatient COPD exacerbations and none were associated with respiratory failure. Changes in arterial oxygen saturation with exacerbations were also small in this study. We found that patients with poorer lung function had higher plasma ET-1 levels, although there was no relationship between stable ET-1 levels and arterial blood gas tensions. The higher ET-1 levels in patients with poorer lung function were probably due to the increased airway inflammation seen in patients with progressive COPD. ${ }^{33}$

ET-1 is known to be a potent coronary vasoconstrictor and has been implicated in the development of coronary endothelial abnormalities. ${ }^{30}$ The incidence of acute ischaemic events is increased shortly after upper respiratory tract infections. ${ }^{34}$ There is also epidemiological evidence that there is increased cardiovascular risk in patients with COPD, even when allowing for smoking history. ${ }^{35}$ One mechanism for this may be the increase in plasma fibrinogen levels seen during exacerbations of $\mathrm{COPD}^{36}$ with systemic ET-1 levels possibly also playing a part. It is possible that acute viral respiratory infections increase airway and thus systemic ET-1 levels, thereby exerting an effect on the coronary circulation. In our study there was a trend towards higher ET-1 levels in the presence of documented infection and this may provide a possible explanation for the relationship between infection and ischaemic heart disease.

In conclusion, sputum ET-1 levels increase during exacerbations of COPD and may play a part in mediating airway inflammatory changes at exacerbation. There are only a few interventions available for treating COPD exacerbations and these are only moderately effective. 
The use of ET receptor antagonists to treat exacerbations may provide a new important therapeutic option in reducing the morbidity and mortality associated with this disabling condition, with potential benefits both within the lung and the coronary circulation.

Dr Roland is supported by a Clinical Training Fellowship provided by the Joint Research Board, St Bartholomew's Hospital Special Trustees. The authors wish to thank Dr Rhian HarperOwen and Dr Mandy Woods.

1 Yanagisawa $M$, Kurihara H, Kimura S, et al. A novel potent vasoconstrictor peptide produced by vascular endothelia cells. Nature 1988;332:411-5.

2 Redington AE, Springall DR, Ghatei MA, et al. Endothelin in bronchoalveolar lavage fluid and its relation to airflow obstruction in asthma. Am $\mathcal{F}$ Respir Crit Care Med 1995;151:1034-9.

3 Hay DW. Putative mediator role of endothelin-1 in asthma and other lung diseases, Clin Exp Pharmacol Physiol 1999;26:168-71.

4 Mullol J, Baraniuk JN, Logun C, et al. Endothelin-1 induces GM-CSF, IL-6 and IL-8 but not G-CSF release from human bronchial epithelial cell line (BEAS-2B). Neuropeptides 1996;30:551-6.

5 Springall DR, Howarth $\mathrm{PH}$, Counihan $\mathrm{H}$, et al. Endothelin Springall DR, Howarth $\mathrm{PH}$, Counihan $\mathrm{H}$, et al. Endothelin immunoreactivity of airway epithe

6 Giaid A. Nitric oxide and endothelin-1 in pulmonary hypertension. Chest 1998;114:208-12S.

7 Ehrenreich H, Anderson RW, Fox CH, et al. Endothelins, peptides with potent vasoactive properties, are produced by human macrophages. $\mathcal{F}$ Exp Med 1990;172:1741-8.

8 Faller DV. Endothelial cell responses to hypoxic stress. Clin Exp Pharmacol Physiol 1999;26:74-84.

9 Carr MJ, Spalding LJ, Goldie RG, et al. Distribution of immunoreactive endothelin in the lungs of mice during respiratory viral infection. Eur Respir F 1998;11:79-85.

10 Warner TD, Klemm P. What turns on the endothelins? Inflamm Res 1996;45:51-3.

11 Chalmers GW, Macleod KJ, Sriram S, et al. Sputum endothelin-1 is increased in cystic fibrosis and chronic obstructive pulmonary disease. Eur Respir f 1999;13:1288obstruct

12 Sofia M, Mormile M, Faraone S, et al. Increased 24-hour endothelin-1 urinary excretion in patients with chronic endothelin-1 urinary excretion in patients with chronic

13 Seemungal TAR, Bhowmik A, Sapsford RJ, et al. Detection of rhinovirus in induced sputum at exacerbations of chronic obstructive pulmonary disease. Eur Respir $\mathcal{F} 2000$ (in press).

14 Gump DW, Phillips CA, Forsyth BR, et al. Role of infection in chronic bronchitis. Am Rev Respir Dis 1976;113:465-74

15 Harper-Owen R, Seemungal TAR, Bhowmik A, et al. Virus and chlamydia isolation in COPD exacerbation (abstract) Eur Respir F 1999;14:46s.

16 British Thoracic Society. BTS guidelines for the management of chronic obstructive pulmonary disease. Thorax 1997;52(Suppl 5):S1-28.

17 Pitkin AD, Roberts CM, Wedzicha JA. Arterialised ear lobe blood gas analysis: an underused technique. Thorax 1994;49:364-6.
18 Anthonisen NR, Manfreda J, Warren CPW, et al. Antibiotic therapy in exacerbations of chronic obstructive pulmonary disease. Ann Intern Med 1987;106:196-204.

19 Seemungal TAR, Donaldson GC, Paul EA, et al. Effect of exacerbation on quality of life in patients with chronic obstructive pulmonary disease. Am $\mathcal{F}$ Respir Crit Care Med 1998;157:1418-22.

20 Bhowmik A, Seemungal TAR, Sapsford RJ, et al. Comparison of spontaneous and induced sputum for investigation of airway inflammation in chronic obstructive pulmonary disease. Thorax 1998;53:953-6.

21 Pin I, Gibson PG, Kolendowicz R, et al. Use of induced sputum cell counts to investigate airway inflammation in asthma. Thorax 1992;47:25-9.

22 Maggi CA, Giuliani S, Patacchini R, et al. The activity of peptides of the endothelin family in various mammalian smooth muscle preparations. Eur f Pharmacol 1989;174: 23-31.

23 Johnston SL, Sanderson G, Pattemore PK, et al. Use of polymerase chain reaction for diagnosis of picornavirus infection in subjects with and without respiratory symptoms. F Clin Microbiol 1993;31:111-7.

24 Cunningham AF, Johnston SL, Julious SA, et al. Chronic chlamydia pneumoniae infection and asthma exacerbations in children. Eur Respir 7 1998;11:345-9.

25 Chalmers GW, Little SA, Patel KR, et al. Endothelin-1induced bronchoconstriction in asthma. Am $\mathcal{F}$ Respir Crit Care Med 1997;156:382-8

26 Vittori E, Marini M, Fasoli A, et al. Increased expression of endothelin in bronchial epithelial cells of asthmatic patients and effect of corticostereoids. Am Rev Respir Dis 1992;146: $1320-5$

27 Nakano J, Takizawa H, Ohtoshi T, et al. Endotoxin and proinflammatory cytokines stimulate endothelin-1 expression and release by airway epithelial cells. Clin Exp Allergy 1994; 24:330-6.

28 Chalmers GW, Thomson L, Macleod KJ, et al. Endothelin-1 levels in induced sputum samples from asthmatic and normal subjects. Thorax 1997;52:625-7.

29 Davies L, Angus RM, Calverley PMA. Oral corticosteroids in patients admitted to hospital with exacerbations of chronic obstructive pulmonary disease: a prospective chronic obstructive pulmonary disease: a prospecti

30 Miyauchi T, Masaki T. Pathophysiology of endothelin in the cardiovascular system. Anпu Rev Physiol 1999;61:391-415.

1 Finsnes F, Skonsberg OH, Tonnessen T, et al. Endothelin production and effects of endothelin antagonism during experimental airway inflammation. Am $\mathcal{f}$ Respir Crit Care Med 1997;155:1404-12.

32 Fleming HE, Little FF, Schnurr D, et al. Rhinovirus-16 colds in healthy and in asthmatic subjects. Am F Respir Crit Care Med 1999;160:100-8.

33 Stanescu D, Sanna A, Veriter C, et al. Airway obstruction, chronic expectoration and rapid decline in $\mathrm{FEV}_{1}$ in smokers are associated with increased levels of sputum neutrophils. Thorax 1996;51:267-71.

34 Meier CR, Jick SS, Derby LE, et al. Acute respiratory tract infections and risk of first-time acute myocardial infarction. Lancet 1998;351:1467-71.

35 Jousilahti P, Vartainen E, Tuomilehto J, et al. Symptoms of chronic bronchitis and the risk of coronary disease. Lancet 1996;348:567-72.

36 Wedzicha JA, Seemungal TAR, MacCallum P, et al. Acute exacerbations of chronic obstructive pulmonary disease are accompanied by elevation of plasma fibrinogen and serum IL-6 levels. Thromb Haemost 2000;84:210-5. 